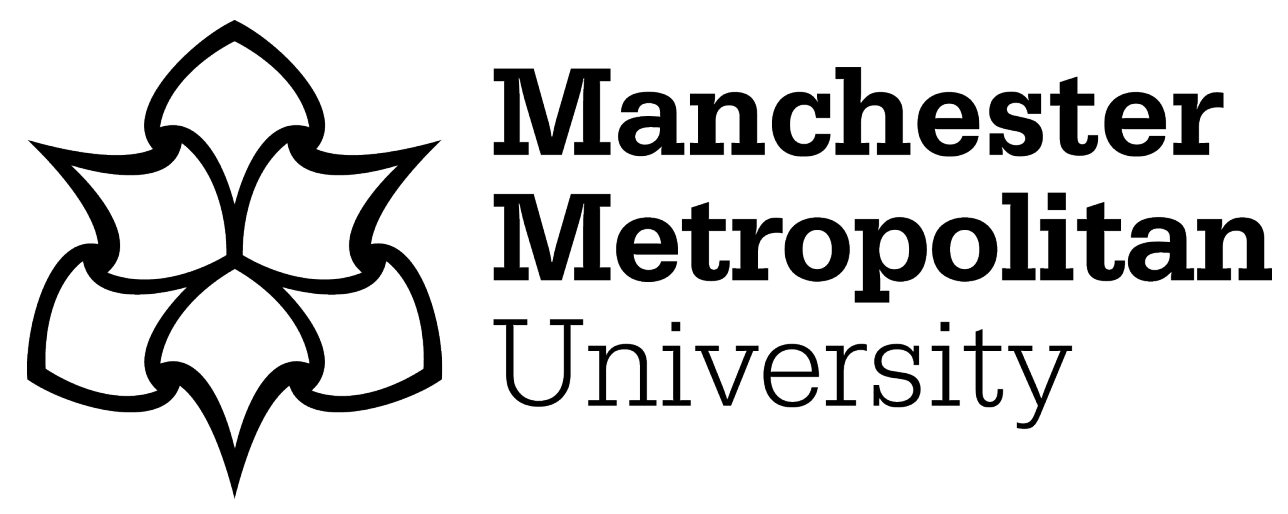

Francescucci, A, Henneberg, SC and Naude, P (2018) Scale development for the inter-firm market orientation concept. Journal of Business and Industrial Marketing, 33 (3). pp. 253-264. ISSN 0885-8624

Downloaded from: https://e-space.mmu.ac.uk/618928/

Version: Accepted Version

Publisher: Emerald

DOI: https://doi.org/10.1108/JBIM-09-2016-0225

Please cite the published version 


\title{
SCALE DEVELOPMENT FOR THE INTER-FIRM MARKET ORIENTATION CONCEPT
}

\author{
Anthony Francescucci \\ Ted Rogers School of Management, Ryerson University, 350 Victoria Street, Toronto, Ontario \\ M5B 2K3, Canada \\ Stephan C. Henneberg \\ Queen Mary University of London, School of Business and Management, Mile End, London \\ E1 4NS, United Kingdom \\ Peter Naudé \\ Manchester Metropolitan University Business School, All Saints Campus, Oxford Road, \\ Manchester M15 6BH, United Kingdom \\ and \\ University of Sydney Business School, Sydney, NSW, Australia
}




\begin{abstract}
Purpose: The objective of this paper is to develop and validate a scale for inter-firm market orientation (IMO) based on an original conceptualization by Elg (2008). Building on the MARKOR scale development work, the inter-firm market orientation (IMO) scale is introduced in order to better understand the market orientation efforts that occur within business relationships.
\end{abstract}

Design/methodology/approach: After establishing a conceptualization of IMO, an initial list of scale items was developed by adapting the original MARKOR scale. Several phases of qualitative pre-tests were conducted with both academic experts and several manufacturer and reseller partner executives in order to assess the applicability and clarity of the instrument. Using a quantitative survey design, the survey instrument was validated with relationship partner managers in a combination of both manufacturer and reseller companies.

Findings: The results of the analysis reveal that IMO is a second-order formative construct consisting of two first-order reflective constructs labelled joint intelligence cooperation and joint customer responsiveness.

Practical implications: The operationalization of IMO suggests to manufacturers and their partners that the market intelligence cooperation efforts between them should be more focused on intelligence about the end-users, and less on the general market trends. Furthermore, the customer responsiveness efforts between the partners tend to be more reactive in nature, unlike the proactive stance in intra-firm market orientation. 
Originality/value: The paper extends the notion of focal firm market orientation to IMO, which exists between partners in business relationships, and does so by developing a conceptualization and measurement items for IMO. This newly developed construct and scale can be used in future research to explore in greater depth the interplay between IMO and firm performance.

\section{Key words}

Inter-firm Market Orientation, Scale Development, Business Relationships, Firm Performance, MIMIC Modeling, Channel Partners 


\section{SCALE DEVELOPMENT FOR THE INTER-FIRM MARKET ORIENTATION CONCEPT}

(Revised title)

\section{Introduction}

The study of market orientation (MO) originated in the early 1990s (Deshpande and Webster Jr., 1989; Kohli and Jaworski, 1990; Narver and Slater, 1990; Day, 1994) as a framework for the implementation of the marketing concept that was originally developed by Barksdale and Darden (1971) and McNamara (1972). While MO has often been studied for its impact in consumer markets, research has also considered the impact of MO in business relationships (Siguaw, Simpson and Baker, 1998; Baker, Simpson and Siguaw, 1999; Langerak, 2001a, 2001b; Grunert et al., 2002; Martin and Grbac, 2003; Min, Mentzer and Ladd, 2007). Studies within the business-to-business (B2B) field have considered a number of consequences of MO, such as performance, or behavioural and employee-related outcomes (Shoham, Rose and Kropp, 2005; van Raaij and Stoelhorst, 2008). While there has been much consideration of the MO of manufacturers as well as of distribution channel members, most of the research to date has been focused on a focal firm perspective, i.e. the focus was on what can be termed 'intra-firm market orientation.' Little is known about aspects of MO within business relationships, i.e. inter-firm market orientation (IMO), which refers to the joint market orientation efforts that take place between manufacturers and their channel partners in supply networks. The objective of this research is to develop a conceptualization and a measurement scale of IMO as a useful concept for future research, including IMO as an additional construct in the often-studied MOperformance relationship.

While the resource-based view of the firm (RBV) (Birger and Wernerfelt, 1984; Barney, 1991) and transaction cost economics (TCE) (Williamson, 1981) would support a view of intra- 
firm market orientation, using an interaction approach (IA) (Ford and Håkansson, 2006a) challenges the traditional view of MO on the basis of structure and process. TCE suggests that business relationships are a cost of doing business and that they should be governed so as to safeguard against opportunism (Johanson and Mattsson, 1987). Given that the focus of TCE is on the focal firm, this would support the view that MO should be studied from a focal-firm perspective. Similarly, the RBV regards relationships as assets for building sustainable competitive advantage (Hogan and Armstrong, 2001), which also suggests a focal firm perspective. Both TCE and RBV are focal firm perspectives that govern how firms interact with other firms based on independent action. The conceptualization of MO supports these perspectives in that $\mathrm{MO}$ considers what the focal firm does from an intelligence gathering (IG) and dissemination (ID) perspective, resulting in a focal firm's customer response (CR) based on that intelligence. Finally, the study of MO has traditionally considered the impact on focal firm performance (i.e. the independent action - IG, ID and CR - on focal firm performance).

By contrast, the IA argues that the "economic world consists of networks of interconnected relationships between interdependent companies" and "the process of business is one of interaction that takes place within business relationships" (Ford and Håkansson, 2006b, pp. 5-6). Thus, the IA asserts that firms are not independent entities acting on their own. On the contrary, the IA suggests that it is not enough for managers to consider only what takes place inside a business to explain performance, but that they also need to consider the interactions between companies (Håkansson et al., 2009). Therefore, if one is to study the performance of a company in an interactive business network, it is necessary to look at the interaction characteristics and how these interactions manifest themselves between companies within business relationships. Consequently, when studying MO, it is necessary to also consider the 
joint market orientation efforts that occur between the business partners, such as a manufacturing company and its channel partners. In this study, the authors introduce a conceptualization of inter-firm market orientation (IMO), and develop an operationalization, i.e. a scale and measurement model to capture it.

This study contributes to the body of knowledge on market orientation by developing an operationalization for IMO. This is key because in the context of business relationships, it is important to understand market orientation within collaborative and cooperative business interactions. This would allow future research to investigate the role that IMO plays in the often studied MO-performance relationship; of particular interest in this context is how intra-firm MO aspects and inter-firm MO aspects impact relationship performance as well as focal-firm business performance. Our conceptualization and operationalization of IMO will allow future researchers to consider models that include an IMO construct, which will enable a better understanding of the role that joint market orientation activities have on performance within business relationships.

The paper begins by reviewing the literature on MO and IMO. Thereafter the research design is presented, followed by the empirical analysis and a review of the findings. The paper ends by discussing the theoretical and managerial implications as well as the limitations of this study, and offers suggestions for future research.

\section{Market Orientation in the Context of Business Relationships}

The research on market orientation originated in studies defining the dimensions of MO, as well as understanding their effects on firm performance. The seminal work on MO includes that of Deshpande and Webster (1989), Kohli and Jaworski (1990), Narver and Slater (1990) and 
Day (1994). This research will take as its starting point a behavioral conceptualization of MO, which can be defined as;

"the organization-wide generation of market intelligence pertaining to customers, competitors, and forces affecting them, internal dissemination of the intelligence, and reactive as well as proactive responsiveness to the intelligence." (Jaworski and Kohli, 1996, p. 131)

The conceptualization of MO can be classified as behavioral (Kohli and Jaworski, 1990; Day, 1994) or cultural (Narver and Slater, 1990; Deshpande, Farley and Webster Jr, 1993). While both approaches have merit, the cultural approach is often problematic to operationalize and measure (Deshpande, Farley and Webster Jr, 1993). Organizational culture is difficult to change, or may take longer periods of time to change (Pelham and Wilson, 1996) and its measurement may introduce 'social desirability bias' when compared to the measure of behavior or activities (Jaworski and Kohli, 1996). When studying MO in the context of business relationships, it is not realistic to assume that companies engaged in joint market orientation activities will have the same organizational culture (Wuyts and Geyskens, 2005). Although Narver and Slater (1990) define market orientation as cultural, it is notable that their operationalization of their measure of the concept is behavioral or activity-oriented.

Since the initial work on MO in the 1990s, research that looks at the role of the value chain or of value networks on the market orientation - performance relationship has been abundant. It has included conceptualizations of MO at the industry level (Grunert et al., 2002), the perspective of other value chain members (Siguaw, Simpson and Baker, 1998; Baker, Simpson and Siguaw, 1999; Langerak, 2001a), the effect of MO on channel relationships (Langerak, 2001b), and the role of supply chain management in market orientation - 
performance relationships (Martin and Grbac, 2003; Min, Mentzer and Ladd, 2007). However, the research to date remains focused on a focal firm perspective of $M O$ and does not look at the joint efforts of the members in the network. Rather, the existing research considers each party's perceptions of market orientation of the other member in the relationship, but does not look at joint market orientation (i.e. what the parties do together).

In a related strand of studies to the value chain research, there has been considerable interest in inter-firm cooperation (Rindfleisch and Moorman, 2003; Hyvönen and Tuominen, 2007; Song, Di Benedetto and Zhao, 2008) and alliance orientation (Kandemir, Yaprak and Cavusgil, 2006). It has been argued that "through cooperation, firms can improve their market understanding and their ability to adapt to their environment" (Elg, 2008, p. 55). Cooperation has been defined as "similar or complementary coordinated actions taken by firms in interdependent relationships to achieve mutual outcomes or singular outcomes with expected reciprocation over time" (Anderson and Narus, 1990, p. 45). While both inter-firm cooperation and alliance orientation are relational concepts, which consider the coordinated or joint efforts of both parties in a relationship, the challenge is that they represent joint efforts between companies that are targeting the same customers, i.e. the involved parties have a similar position in the network. For example, manufacturing companies may cooperate in joint new product development activities designed to leverage the core strengths of the respective companies to develop a product targeted at the same customer. The cooperating or aligned companies are therefore not in a supplier-customer relationship, and are often competitors in 'coopetition' situations (Bengtsson and Kock, 2000). By contrast, the focus of this research is on business relationships that involve a buyer and supplier in a channel partner relationship, i.e. interactions between partners who exchange offerings with each other and not those who are competitors in a 
'coopetition' relationship. In this paper, the focus is on IMO, which considers the joint market orientation efforts of two parties who are in a channel relationship (i.e. are in a supplier-channel partner relationship). Consequently, the strategies and goals of these two companies may not be completely aligned and therefore IMO is conceptualized in a different way to inter-firm cooperation in alliance situations.

The concept of IMO is innovative and has gained little attention in the literature to date. In this context, the studies by Elg (2007) and Elg and Paavola (2008) are noteworthy. Their work was the first to consider the combined market orientation activities between a manufacturer and their partners. To our knowledge, IMO has not been operationalized, nor has a scale been developed to measure it. Previous research focuses on outlining the IMO concept, for example Elg (2008, p. 56) defines inter-firm market orientation as "the activities that two or more independent companies carry out together to make a network or an individual relationship more sensitive to the demands of the market." He goes further to describe the elements of IMO based on the Kohli and Jaworski's (1990) conceptualization of MO, i.e. as consisting of joint intelligence generation, joint intelligence dissemination, and collective responsiveness to customer needs. Joint intelligence generation occurs when two or more firms in the relationship work together to obtain knowledge about the end-user customer. Joint intelligence dissemination consists of sharing of information between firms within the network to provide all members with better information about the end-customer. Collective responsiveness includes firms within the network coordinating their efforts to provide an offer to the end-customer, which better meets their needs (Elg, 2008). The key differentiator to a focal firm conceptualization of MO is that IMO is conceptualized as the joint efforts of channel members, and not the individual efforts of the firms. The aim of their joint activities is to optimize offerings for the end-user customer, 
who may buy an offering (manufactured by the supplier company) via a reseller (the channel partner). See table 1 for a representative summary of the research on MO and IMO.

[Insert Table 1 Here]

For the purposes of this study, IMO is conceptualized as a formative second-order construct that includes the joint activities of a manufacturer and a channel partner in intelligence generation, intelligence dissemination, and proactive and reactive responsiveness to customer needs as reflective first-order constructs. In the context of our study, of the business relationships between a manufacturer and a wholesaler/reseller, it is insufficient to investigate MO solely from a focal firm perspective because most manufacturers do not sell their goods directly to the end customer. Often manufacturers use a network of partners to get their product offerings to market. To investigate the impact of $\mathrm{MO}$ in $\mathrm{B} 2 \mathrm{~B}$ relationships, it is necessary to understand what manufacturers and their partners do jointly from a market orientation perspective. Therefore, it is necessary to consider the joint market orientation efforts between a manufacturer and its channel partners. While the concept of IMO has been advanced in the literature in this context, research published to date has been primarily conceptual and qualitative using case study analysis (Elg, 2007, 2008). In contrast, this study develops a scale for IMO using quantitative methods.

Finally, there has been much debate in the literature regarding whether second-order latent constructs, with reflective first-order constructs, should be modeled as reflective or formative (Jarvis, MacKenzie and Podsakoff, 2003; MacKenzie, Podsakoff and Jarvis, 2005; Diamantopoulos, Riefler and Roth, 2008; Cadogan, Lee and Chamberlain, 2013). Lee et al. (2013) argue that second-order constructs should not be modeled as reflective but rather should be modeled as formative because reflective higher-order measurement models are not valid when 
the lower-order constructs are not conceptually identical or interchangeable. These two factors (identical concepts and interchangeability) would be indicative of reflective and not formative constructs. Furthermore, reflective measures cannot contain multiple dimensions designed to capture different aspects of the same construct. Given that IMO is conceptualized as consisting of a combination of dimensions (first order constructs) that include different joint activities of a manufacturer and a channel partner in terms of intelligence generation, intelligence dissemination, and proactive and reactive responsiveness to the customer, each of these first order constructs are not conceptually identical, nor can they be used interchangeably. Consequently, the authors follow Lee et al.'s (2013) perspective on higher-order constructs and therefore model and test inter-firm market orientation as a formative second-order construct with reflective first-order factors using a MIMIC test.

\section{Research Design}

\subsection{Scale Development}

In order to develop an scale for inter-firm market orientation (i.e. a measurement model), an initial list of scale items for IMO was developed by adapting the Kohli et al. (1993) MARKOR scale to reflect joint market orientation efforts between a manufacturer and their channel partners. The MARKOR scale items were chosen because of the behavioral conceptualization of IMO. Initially the MARKOR scale items were adapted to represent joint activities that take place between a manufacturer and their partner, in line with the conceptualization of IMO. While the final MARKOR scale developed by Kohli et al. (1993) to measure MO was reduced to include only 20 items in its final measurement model, the 31 original items were used in the development of the IMO measurement model in order to 
determine if there were items that may be relevant for IMO. The decision to begin with 31 items from the MARKOR scale is consistent with procedures that suggest that scale development should begin with a large number of seemingly overlapping items, as small nuances of meaning may result in different outcomes (Churchill, 1979). All indicators were reflective (Diamantopoulos and Siguaw, 2006).

Next, these scales were used in different phases of a qualitative pre-test. First, three academics with expertise in business-to-business marketing as well as quantitative research were asked to review and critically evaluate the newly adapted scale items within the context of the joint marketing efforts that take place between a manufacturer and its partners (Blair and Presser, 1992). Items that were unclear were identified and reworded. On the basis of their input, all 31 items remained; however, the wording of some of the items was slightly changed. Secondly, the resulting items were used in a questionnaire, which was tested with five manufacturer and five reseller partner executives to assess the applicability and clarity of the survey instruments within their existing relationships (Blair and Presser, 1992). The respondents were asked to complete the survey and identify any item wordings that were unclear, or not applicable to their relationships. Again, a small number of item wordings were changed as a result of this pre-test but no items were removed from the scale list at this point (see appendix).

\subsection{Research Method and Sample}

Based on the questionnaire developed, this study uses a quantitative survey design to test the measurement scales for IMO. The sample for the quantitative survey was drawn from the member companies of the Institute for the Study of Business Markets (ISBM). Several manufacturer companies were contacted to solicit their participation in the study. Overall, four companies agreed to participate. They included two companies from Canada, one from the 
United States and one from Europe. The companies were from the information technology and the industrial supplies industries. The participating companies distributed the survey to their knowledgeable employees who were responsible for managing partner (reseller) relationships. A snowballing technique was used, where the manufacturers' partner managers were asked to think about a particular partner relationship while completing the survey and to provide the contact information for their peer within the reseller company who was responsible for managing the relationship with them. This partner was then contacted and asked to complete the same survey while thinking about the manufacturer company who had provided their contact information. Finally, to ensure the sampling of key informants for this survey, respondents were asked to rate their knowledge in completing the survey on a five point Likert scale (where 1 is "not at all knowledgeable" and 5 is "extremely knowledgeable"). Responses that scored equal/less than three on the knowledge scale were removed from the sample. A total sample of 130 responses (91 manufacturers and 39 resellers) was collected. The average number of years a respondent had been with their company was ten. The average number of years a respondent had been in their current position was 5.5. Table 2 below provides additional information on the characteristics of the sample. Given that the manufacturing companies were responsible for distributing the survey to their employees, no response rate can be calculated.

[Insert Table 2 Here]

A test was conducted to measure the potential impact of common method bias that may result due to the proximity of items in the survey instrument when collecting data for dependent and independent constructs from the same source (Podsakoff, MacKenzie and Podsakoff, 2012). The test consisted of analyzing the correlations between a marker variable and the measurement model constructs (Lindell and Whitney, 2001). The variable number of years with employer was 
chosen as a marker variable because it is theoretically unrelated with the measurement model constructs. As suggested by Weijters, Geuens and Schillewaert (2009), common method bias exists when the correlations between the marker variable and other constructs depends on the proximity of the relevant items in the questionnaire. Our analysis of the correlation between the marker variable and the construct items indicates that $\mathrm{CMV}$ is not problematic.

The issue of non-response bias was tested to see if there were differences between those participants who did respond to the original survey and those who had not. Participants from the manufacturer who did not respond to the original survey were sent another survey asking them to complete a shorter questionnaire concerning only demographic questions (regarding their company as well as themselves). We then compared the same demographic indicators between those respondents who had responded to the original survey with those who had not. T-test comparisons indicated no significant differences, suggesting the absence of a non-response bias.

\subsection{Analysis and Results}

Prior to analyzing the data, the authors reviewed the necessary statistical measures to assess the distribution of the data as well as the randomness of any missing data. Missing data was completely random; thus the expectation maximization method within the missing value analysis module was used to address any issues with missing data (Hair et al., 2010). An exploratory factory analysis (EFA) with oblique rotation was conducted, followed by a confirmatory factor analysis (CFA) using AMOS Version 21 (Arbuckle, 2006) to refine and validate the measurement models for IMO. As a robustness check, two random samples were created consisting of two-thirds of the original sample. A new EFA analysis was done using one of the two-thirds samples created from the original. Finally, the second two-thirds sample was used to validate IMO as a formative second-order construct consisting of two first-order 
reflective constructs. To do this second-order analysis, a MIMIC (multiple indicators and multiple cases) test was performed (Diamantopoulos, Riefler and Roth, 2008; Thornton, Henneberg and Naude, 2014).

\subsubsection{Initial Exploratory Factor Analysis}

The initial EFA of the inter-firm market orientation scale included the list of 31 IMO items that describe the joint marketing efforts between manufacturers and reseller partners. In the first pass of the EFA analysis, it was determined that the reverse coded items caused many items to load incorrectly onto factors that were inconsistent with the theory. Previous research suggests that negatively worded items may provide different factor structures than positively worded items and that negatively worded items should be excluded from factor analyses (Schriesheim and Eisenbach, 1995; Woods, 2006). The authors removed the ten reverse coded items and repeated the analysis. Following that, eleven items which did not load particularly strongly onto any factor, or where redundant, were removed as well.

The final EFA resulted in two factors, with a total of nine items for the measurement model. The two resulting factors were termed joint intelligence cooperation (JIC) and joint customer responsiveness (JCR). While the EFA analysis resulted in only nine items from the original 31 , it is important to note that the scale development process began with many more items than would be necessary for the final IMO scale (following the procedure suggested by (Churchill, 1979). This is consistent with the development of the MARKOR scale (Kohli, Jaworski and Kumar, 1993) which began with 31 items and was subsequently reduced to only 21 items in it final scale. Finally, given that IMO is conceptualized as different to MO, and as a two sub-construct model, it is appropriate for the IMO factors to differ significantly from the MO factors. Therefore, the nine-item two sub-construct scale is considered adequate. 
Next, the authors tested each factor and the associated indicators for reliability using the Cronbach's Alpha reliability test. The final EFA results are shown in Table 3. The reliability scores of 0.835 and 0.782 are both within the acceptable range (Nunnally, 1978).

[Insert Table 3 Here]

\subsubsection{Confirmatory Factor Analysis}

Using the two factors developed in the EFA, an initial CFA was conducted. Examination of the standardized residual covariances did not indicate any cross loading between the factors. However, based on the initial results, it was determined that two indicators from JIC and one from JCR should be removed due to significantly overlapping measures. The decision to remove any items from the measurement model was not based exclusively on statistical considerations but also included a check on whether or not the removal of items affected the integrity of the overall construct. With these three indicators removed, the model was reanalyzed resulting in improved fit statistics over the initial model. The final model is illustrated in figure 1 and the correlation matrix for the measurement model variables is illustrated in Table 4. The resulting goodness of fit statistics for this model are: $\chi^{2}=9.727$ (df 8), standardized RMR $=0.039$, GFI $=0.975, \mathrm{CFI}=0.993$ and RMSEA $=0.041$. The fit statistics for this model are well within the acceptable range, therefore suggesting a good fit for the more parsimonious IMO scale.

\section{[Insert Figure 1 and Table 4 Here]}

Using the first of the two two-thirds samples, the EFA was repeated using the same procedures as outlined above. The final EFA resulted in the same two factors with a total of six items. The results are listed in Table 5. The reliability scores of 0.812 and 0.767 are similar to the reliability scores in the initial EFA and are within acceptable ranges (Nunnally, 1978). 


\subsubsection{Formative Second-order Construct MIMIC Test}

Next the authors assessed whether joint intelligence cooperation and joint customer responsiveness together form a single higher-order construct to explain IMO. There has been much debate in the literature to date regarding whether second-order latent constructs, with reflective first-order constructs, should be modeled as reflective or formative second-order constructs (Jarvis, MacKenzie and Podsakoff, 2003; MacKenzie, Podsakoff and Jarvis, 2005; Diamantopoulos, Riefler and Roth, 2008; Cadogan and Lee, 2013). In fact, Jarvis and her colleagues (2003) and Coltman et al. (2008) have argued that the concept of market orientation, which has been historically modeled as a reflective second-order construct with three first-order reflective constructs, has been mis-specified. They argue that MO should be modeled as a formative second-order construct and not as a reflective one. Given that the authors have adapted the IMO operationalization from the original MO operationalization, they can therefore assess whether JIC and JCR can be modeled as a second-order formative construct for IMO.

To assess whether JIC and JCR can be modeled as a formative second-order construct with two first-order reflective constructs, the authors began by testing for high levels of multicollinearity between the constructs that form the second-order construct, followed by an assessment of the multiple indicators and multiple causes (MIMIC) model (Diamantopoulos, Riefler and Roth, 2008; Thornton, Henneberg and Naude, 2014). High levels of multicollinearity, based on variance inflation factors (VIF) would indicate that the two first-order factors do not provide unique contributions to the second-order construct (Diamantopoulos and Winklhofer, 2001). The VIF among the focal constructs range from 1.393 to 2.162, all of which are below the suggested threshold of 10 (Hair et al., 2010) indicating the absence of multicollinearity among the constructs. Next, to assess for external validity, a MIMIC model 
approach was used, which involves assessing a model which connects the second-order formative construct to two other first-order reflective constructs (either antecedents or consequences) which one would expect the second-order construct to link with (Diamantopoulos and Winklhofer, 2001). In our MIMIC analysis, IMO is linked with two consequences; namely relationship performance and business performance (see figure 2).

[Insert Figure 2 Here]

Given that IMO is an inter-organizational or relationship-based construct, it is argued that the outcome should also be a relationship-based construct. Relationship performance is the extent to which the parties in the relationship perceive the relationship to be productive and rewarding from a financial and non-financial perspective (Selnes and Sallis, 2003). Given that both parties in a relationship are engaged in IMO which better meet the needs of their common customer (Elg, 2002) and if the common customer continues to do business with the focal firm and their channel partner, then both parties should perceive their relationship to be more productive and rewarding from a financial as well as non-financial perspective. Furthermore, given that IMO is based on MO and that there exists ample evidence of a positive relationship between MO and focal firm business performance (Jaworski and Kohli, 1993), it is suggested that IMO is positively related to focal firm business performance.

Using the second two-thirds sample, PLS SEM (Ringle, Wende and Will, 2005) is used to assess the validity of the MIMIC model. First, the reliability of the measurement model is assessed. Table 6 provides the internal consistency reliability, convergent and discriminant validity results. Composite reliability scores are above .7 for all latent variables, which is well within the acceptable range suggesting internal consistency reliability. All AVEs are greater than .5 suggesting convergent validity except for business performance. Both the Fornell-Larcker 
calculations and the indicators that loaded onto their respective latent variables had significance levels greater than .001, suggesting discriminant validity (Henseler, Ringle and Sinkovics, 2009). Lastly, the significance levels and the path coefficients for the structural model are assessed. Table 7 provides the significance levels for the paths and their respective coefficients for the structural model of the MIMIC model. All paths are significant at the 0.01 level, except for the IMO to BP path, which is significant at the 0.05 level. Given that both the measurement model and the structural model have good fit parameters, it can be argued that IMO can be modeled as a formative second-order construct with two first-order reflective constructs.

[Insert Tables 6 and 7 Here]

\section{Findings and Discussion}

This research was carried out in order to extend the market orientation literature to account for the role that joint marketing efforts play within business relationships. To date, the market orientation literature has focused nearly exclusively on the singular efforts of a focal firm, e.g. a manufacturer. While the resource-based view of the firm and transaction cost economics would support this approach, the interaction approach suggests that it is not just the focal firm's market orientation efforts alone that should be considered. Rather, one needs to consider also the inter-firm market orientation efforts of the manufacturer and their partners to understand how such an orientation affects firm performance.

The results of our operationalization of IMO indicate that the concept of inter-firm market orientation consists of two factors (JIC and JCR) instead of three as originally hypothesized (JIG, JID, JCR) based on the behavioral MO literature, namely joint intelligence cooperation and joint customer responsiveness. Furthermore, the two factors that make up IMO contain far fewer reliable scale items than originally expected. Manufacturers and their channel 
partners do not appear to separate the joint generation and the joint dissemination of market intelligence effort, but rather view it more as an integrated aspect of cooperation (i.e. the combined effort of joint intelligence generation and joint dissemination). This new construct is termed 'joint intelligence cooperation'.

\subsection{The Sub-construct of Joint Intelligence Cooperation}

The results suggest that when it comes to gathering market intelligence between the manufacturer and their channel partners, the joint generation and dissemination of the intelligence are combined into one factor defined as joint intelligence cooperation (JIC). JIC is the coordinated generation and dissemination of market intelligence between the manufacturer and their partners. Based on the scale items that load onto this factor, much of the joint market intelligence effort is centered on the collection of that intelligence through surveys or market research rather than jointly meeting with end-customers to obtain that intelligence. Similarly, the dissemination or sharing of the market intelligence appears to be through documentation, rather than through regular meetings between the business partners. Finally, all of the intelligence cooperation efforts appear to be focused on end-user customer information, and much less on other market or business trends.

Given that manufacturers typically work with hundreds and sometimes thousands of reselling partners in getting their product to the customer, it is reasonable that their joint market orientation efforts with these partners are focused on the customer and not so much on other market or business trends. The sheer volume of partners would necessitate a focus on key intelligence that would drive the most significant impact on business performance. 


\subsection{The Sub-construct of Joint Customer Responsiveness}

Joint customer responsiveness (JCR) is the combined response effort taken by the manufacturer and their channel partner to respond to customer needs based on the market intelligence shared between them. The scale items that make up this factor would indicate that the responsiveness efforts between the manufacturer and their partner appear to be focused primarily on a reactive instead of a proactive effort. The proactive responsiveness scale items do not appear to load onto this factor as compared to the scale items that make up the original customer responsiveness factor of market orientation.

Many manufacturers work with multiple distribution channel partners in getting their products to market. This requires the manufacturer to have many channel partner managers to organize each of the distribution channel partner relationships. Due to the number of manufacturer partner relationships, it appears that a proactive response effort is difficult to achieve. This may be due in part to the fact that a proactive response effort may require significantly more coordination and resources in terms of time and money. In addition, being able to plan a joint proactive customer response may well require activities involving other parties beyond just the relationship partner managers who manage the relationship. This would increase the resources required to be proactive in a customer response, which in turn may not lead to a justifiable benefit to the organizations. Consequently, the parties focus their efforts on a reactive response basis rather than a proactive one.

\subsection{Theoretical and Managerial Implications of the IMO Construct}

The operationalization of inter-firm market orientation provides insights into the differences between the intra- and inter-firm market orientations (MO and IMO) of firms. While intra-firm MO research suggests there are three distinct constructs, inter-firm MO results in only 
two, with the intelligence generation and intelligence dissemination activities being combined. Furthermore, inter-firm MO contains far fewer indicators than intra-firm MO. This fact indicates that the inter-firm MO efforts between partner firms consist of a more limited set of behaviors, and mainly of reactive aspects as opposed to proactive efforts, given the absence of a number of the proactive indicators in the IMO scale. Finally, with the establishment of an IMO operationalization, it is important to consider what role it may play in the market orientation performance relationship. Further research is necessary to address the question of whether IMO has an effect on the market orientation - performance relationship.

From a more practical perspective, unlike MO, the operationalization of IMO would suggest to manufacturers and their partners that the market intelligence cooperation efforts between the partners should be focused on intelligence about the end-user customer and less about the market in general terms. Furthermore, while intra-firm customer responsiveness efforts include both proactive and reactive efforts, the inter-firm joint customer responsiveness efforts are more reactive. Therefore, in managing business relationships, each firm should put more emphasis on sharing intelligence about the end-user with their partner rather than sharing intelligence about general business trends. Given that a joint proactive response to customer needs between the firm and their partner does not appear to be an important consideration in IMO, investment in efforts of a proactive nature seem not to be warranted. Rather, the firm and their channel partner should concentrate their efforts in responding to end-customer needs on a more reactive basis.

Finally, given that the IMO measurement model is behavior or activity-based, firms could use the IMO scale to establish a benchmark to measure changes in channel partner relationships. This benchmark could be used as a way to evaluate the market orientation efforts of their partner 
relationships. Manufacturers could also use the benchmark to establish goals with their partners as a means of improving their inter-firm market orientation efforts.

\subsection{Limitations and Future Research}

A limitation of this study is the small sample size. Future research may look to replicate the findings in this study with larger samples. Future research could also consider replicating the study using a dyadic perspective of IMO (i.e. a combined indicator consisting of the perception of the manufacturer and their partner for each of the scale items). Another limitation of this study is that the data was collected primarily from North America and to a limited extent from Europe. A future study might attempt to replicate the findings by collecting data in other parts of the world to determine the applicability of inter-firm market orientation. In addition, this study adapted the MARKOR scale items developed by Kohli et al. (1993) and future research may consider the development of inter-firm scale items based on other conceptualizations of market orientation (Narver and Slater, 1990; Deshpande, Farley and Webster Jr, 1993; Day, 1994). Finally, future research in the area of inter-firm market orientation might look at the role that IMO plays in the market orientation - performance relationship. Given that most manufacturers work with partners to get their product to market, it is plausible that IMO could mediate or moderate the relationship between market orientation and business performance. 


\section{References}

Anderson, J. C. and Narus, J. A. (1990) 'A model of distributor firm and manufacturer firm working partnerships', Journal of Marketing, 54(1), pp. 42-58.

Arbuckle, J. L. (2006) 'AMOS (Version 21) [Computer Program]’. Chicago: IBM SPSS.

Baker, T. L., Simpson, P. M. and Siguaw, J. A. (1999) 'The impact of suppliers' perceptions of reseller market orientation on key relationship constructs', Journal of the Academy of Marketing Science, 27(1), pp. 50-57.

Barksdale, H. C. and Darden, B. (1971) 'Marketers' attitudes toward the marketing concept', Journal of Marketing, 35(4), pp. 29-36.

Barney, J. (1991) 'Firm resources and sustained competitive advantage', Journal of Management. Texas A\&M University: Sage Publications, 17(1), pp. 99-120.

Bengtsson, M. and Kock, S. (2000) "'Coopetition" in business networks - to cooperate and compete simultaneously', Industrial Marketing Management. Elsevier Science, 29(5), pp. 411426.

Birger, W. and Wernerfelt, B. (1984) 'A resource-based view of the firm', Strategic Management Journal. John Wiley \& Sons, Ltd., 5(2), pp. 171-180.

Blair, J. and Presser, S. (1992) 'An experimental comparison of alternative pretest techniques: A note on preliminary findings', Journal of Advertising Research. Kogan Page, 32(2), pp. 2-5.

Cadogan, J., Lee, N. and Chamberlain, L. (2013) 'Formative variables are unreal variables: Why the formative MIMIC model is invalid', AMS Review, 3(1), pp. 38-49.

Cadogan, J. W. and Lee, N. (2013) 'Improper use of formative endogenous variables', Journal of business research, 66(2), pp. 233-241.

Churchill, G. A. (1979) 'A paradigm for developing better measures of marketing constructs', Journal of Marketing Research. American Marketing Association, 16(1), pp. 64-73.

Coltman, T., Devinney, T. M., Midgley, D. F. and Venaik, S. (2008) 'Formative versus reflective measurement models: Two applications of formative measurement', Journal of Business Research, 61(12), pp. 1250-1262.

Day, G. S. (1994) 'The capabilities of market-driven organizations', Journal of Marketing, 58(4), pp. 37-52.

Deshpande, R., Farley, J. U. and Webster Jr, F. E. (1993) 'Corporate culture, customer orientation, and innovativeness', Journal of Marketing, 57(1), pp. 23-37.

Deshpande, R. and Webster Jr., F. E. (1989) 'Organizational culture and marketing: Defining the research', Journal of Marketing, 53(1), pp. 3-15.

Diamantopoulos, A., Riefler, P. and Roth, K. P. (2008) 'Advancing formative measurement models', Journal of Business Research, 61(12), pp. 1203-1218.

Diamantopoulos, A. and Siguaw, J. A. (2006) 'Formative versus reflective indicators in organizational measure development: A comparison and empirical Illustration', British Journal of Management, 17(4), pp. 263-282.

Diamantopoulos, A. and Winklhofer, H. M. (2001) 'Index construction with formative 
indicators: an alternative to scale development', Journal of Marketing Research, pp. 269-277. Elg, U. (2002) 'Inter-firm market orientation: Its significance and antecedents in distribution networks', Journal of Marketing Management, 18(7), pp. 633-655.

Elg, U. (2007) 'Market Orientation as Inter-firm Cooperation', European Management Journal, 25(4), pp. 283-297.

Elg, U. (2008) 'Inter-firm market orientation and the influence of network and relational factors', Scandinavian Journal of Management, 24(1), pp. 55-68.

Elg, U. and Paavola, H. (2008) 'Market orientation of retail brands in the grocery chain: the role of supplier relationships', The International Review of Retail, Distribution and Consumer Research, 18(2), pp. 221-233.

Ford, D. and Håkansson, H. (2006a) 'IMP - some things achieved: much more to do', European Journal of Marketing, 40(3/4), pp. 248-258.

Ford, D. and Håkansson, H. (2006b) 'The idea of business interaction', The IMP Journal, 1(1), pp. 4-20.

Grunert, K. G., Risom, K., Sonne, A. M., Hansen, K. and Trondsen, T. (2002) 'Market orientation at industry and value chain levels: concepts, determinants and consequences', Journal of Customer Behaviour, 1(2), pp. 167-194.

Hair, J. F., Black, W. C., Babin, B. J., Anderson, R. E. and Tatham, R. L. (2010) Multivariate data analysis. Upper Saddle River, NJ: Prentice Hall.

Håkansson, H., Ford, D., Gadde, L.-E., Snehota, I. and Waluszewski, A. (2009) Business in networks. Chichester: Wiley and Sons Ltd.

Henseler, J., Ringle, C. M. and Sinkovics, R. R. (2009) 'The use of partial least squares path modeling in international marketing', Advances in International Marketing, 20(1), pp. 277-319.

Hogan, J. E. and Armstrong, G. (2001) 'Toward a resource-based theory of business exchange relationships: The role of relational asset value', Journal of Business-to-Business Marketing, 8(4), pp. 3-28.

Hyvönen, S. and Tuominen, M. (2007) 'Channel collaboration, market orientation and performance advantages: Discovering developed and emerging markets', International Review of Retail, Distribution \& Consumer Research, 17(5), pp. 423-445.

Jarvis, C. B., MacKenzie, S. B. and Podsakoff, P. M. (2003) 'A critical review of construct indicators and measurement model misspecification in marketing and consumer research', Journal of consumer research, 30(2), pp. 199-218.

Jaworski, B. J. and Kohli, A. K. (1993) 'Market orientation: Antecedents and consequences', Journal of Marketing, 57(3), pp. 53-70.

Jaworski, B. J. and Kohli, A. K. (1996) 'Market orientation: review, refinement, and roadmap', Journal of Market-Focused Management, 1(2), pp. 119-135.

Johanson, J. and Mattsson, L.-G. (1987) 'Interorganizational relations in industrial systems: A network approach compared with the transaction-cost approach', International Studies of Management \& Organization, 17(1), pp. 34-48.

Kandemir, D., Yaprak, A. and Cavusgil, S. T. (2006) 'Alliance orientation: Conceptualization, 
measurement, and impact on market performance', Journal of the Academy of Marketing Science, 34(3), pp. 324-340.

Kohli, A. K. and Jaworski, B. J. (1990) 'Market orientation: The construct, research propositions, and managerial implications', Journal of Marketing, 54(2), pp. 1-18.

Kohli, A. K., Jaworski, B. J. and Kumar, A. (1993) 'MARKOR: A measure of market orientation', Journal of Marketing Research, 30(4), pp. 467-477.

Langerak, F. (2001a) 'Effects of market orientation on the behaviors of salespersons and purchasers, channel relationships, and performance of manufacturers', International Journal of Research in Marketing, 18(3), pp. 221-234.

Langerak, F. (2001b) 'The relationship between customer and supplier perceptions of the manufacturer's market orientation and its business performance', International Journal of Market Research, 43(1), pp. 43-62.

Lee, N. and Cadogan, J. W. (2013) 'Problems with formative and higher-order reflective variables', Journal of Business Research, 66(2), pp. 242-247. doi: 10.1016/j.jbusres.2012.08.004.

Lindell, M. K. and Whitney, D. J. (2001) 'Accounting for common method variance in crosssectional research designs’, Journal of Applied Psychology. Elsevier Science, 86(1), pp. 114121. doi: 10.1037/0021-9010.86.1.114.

MacKenzie, S. B., Podsakoff, P. M. and Jarvis, C. B. (2005) 'The problem of measurement model misspecification in behavioral and organizational research and some recommended solutions', Journal of Applied Psychology, 90(4), pp. 710-730.

Martin, J. H. and Grbac, B. (2003) 'Using supply chain management to leverage a firm's market orientation', Industrial Marketing Management, 32(1), pp. 25-38.

McNamara, C. P. (1972) 'The present status of the marketing concept', Journal of Marketing, 36(1), pp. 50-57.

Min, S., Mentzer, J. and Ladd, R. (2007) 'A market orientation in supply chain management', Journal of the Academy of Marketing Science, 35(4), pp. 507-522.

Narver, J. C. and Slater, S. F. (1990) 'The effect of a market orientation on business profitability', Journal of Marketing, 54(4), pp. 20-35.

Nunnally, J. C. (1978) Psychometric theory. New York: McGraw-Hill.

Pelham, A. M. and Wilson, D. T. (1996) 'A longitudinal study of the impact of market structure, firm structure, strategy, and market orientation culture on dimensions of small-firm performance', Journal of the Academy of Marketing Science, 24(1), pp. 27-43.

Podsakoff, P. M., MacKenzie, S. B. and Podsakoff, N. P. (2012) 'Sources of method bias in social science research and recommendations on how to control it', Annual Review of Psychology, 63(1), pp. 539-569.

van Raaij, E. M. and Stoelhorst, J. W. (2008) 'The implementation of a market orientation', European Journal of Marketing, 42(11/12), pp. 1265-1293.

Rindfleisch, A. and Moorman, C. (2003) 'Interfirm cooperation and customer orientation', Journal of Marketing Research, 40(4), pp. 421-436. 
Ringle, C. M., Wende, S. and Will, S. (2005) 'SmartPLS 2.0 (M3) Beta'. Hamburg.

Schriesheim, C. and Eisenbach, R. (1995) 'An exploratory and confirmatory factor-analytic investigation of item wording effects on the obtained factor structures of survey questionnaire measures', Journal of Management, 21(6), pp. 1177-1193.

Selnes, F. and Sallis, J. (2003) 'Promoting relationship learning', The Journal of Marketing. American Marketing Association, 67(3), pp. 80-95.

Shoham, A., Rose, G. M. and Kropp, F. (2005) 'Market orientation and performance: a metaanalysis', Marketing Intelligence \& Planning, 23(5), pp. 435-454.

Siguaw, J. A., Simpson, P. M. and Baker, T. L. (1998) 'Effects of supplier market orientation on distributor market orientation and the channel relationship: The distributor perspective', Journal of Marketing, 62(3), pp. 99-111.

Song, M., Di Benedetto, C. A. and Zhao, Y. (2008) 'The antecedents and consequences of manufacturer-distributor cooperation: an empirical test in the US and Japan', Journal of the Academy of Marketing Science, 36(2), pp. 215-233.

Thornton, S. C., Henneberg, S. C. and Naude, P. (2014) 'Conceptualizing and validating organizational networking as a second-order formative construct', Industrial Marketing Management, 43(6), pp. 951-966.

Weijters, B., Geuens, M. and Schillewaert, N. (2009) 'The proximity effect: The role of interitem distance on reverse-item bias', International Journal of Research in Marketing, 26(1), pp. $2-12$.

Williamson, O. E. (1981) 'The economics of organization: The transaction cost approach', American Journal of Sociology, 87(3), pp. 548-577.

Woods, C. M. (2006) 'Careless responding to reverse-worded items: Implications for confirmatory factor analysis', Journal of Psychopathology and Behavioral Assessment, 28(3), pp. 186-191.

Wuyts, S. and Geyskens, I. (2005) 'The formation of buyer-supplier relationships: Detailed contract drafting and close partner selection', Journal of Marketing, 69(4), pp. 103-117. 
Table 1: Summary of Key Market Orientation Research

\begin{tabular}{|l|l|c|l|}
\hline \multicolumn{1}{|c|}{ Study } & Theoretical Lens & Approach & \multicolumn{1}{|c|}{ Key Contribution } \\
\hline \multicolumn{3}{|c|}{ Seminal work MO } \\
\hline $\begin{array}{l}\text { Kohli \& Jaworski } \\
\text { (1990) }\end{array}$ & Not identified & Behavioral & Theoretical Development of MO \\
\hline $\begin{array}{l}\text { Narver \& Slater (1990) } \\
\text { Resource-based } \\
\text { View }\end{array}$ & Cultural & $\begin{array}{l}\text { Positive Relationship between MO } \\
\text { and Performance }\end{array}$ \\
\hline $\begin{array}{l}\text { Deshpande, Farley \& } \\
\text { Webster (1993) }\end{array}$ & $\begin{array}{l}\text { Organizational } \\
\text { Behavior \& TCE }\end{array}$ & Cultural & $\begin{array}{l}\text { Positive Relationship between MO } \\
\text { and Performance }\end{array}$ \\
\hline Day (1994) & $\begin{array}{l}\text { Total Quality } \\
\text { Management }\end{array}$ & Cultural & Theoretical Development of MO \\
\hline \multicolumn{3}{|c|}{ Representative further work on MO } \\
\hline $\begin{array}{l}\text { Siguaw, Simpson \& } \\
\text { Baker (1998) }\end{array}$ & $\begin{array}{l}\text { Relational } \\
\text { Norms }\end{array}$ & Behavioral & $\begin{array}{l}\text { Positive Relationship between MO } \\
\text { and Performance }\end{array}$ \\
\hline $\begin{array}{l}\text { Baker, Simpson \& } \\
\text { Siguaw (1999) }\end{array}$ & $\begin{array}{l}\text { Cooperative } \\
\text { Norms }\end{array}$ & Cultural & $\begin{array}{l}\text { Positive Relationship between MO } \\
\text { and Trust, Cooperative Norms, } \\
\text { Commitment \& Satisfaction }\end{array}$ \\
\hline Langerak (2001b) & $\begin{array}{l}\text { Organizational } \\
\text { Behavior \& TCE }\end{array}$ & Cultural & $\begin{array}{l}\text { Positive Relationship between MO } \\
\text { and Performance }\end{array}$ \\
\hline Grunert et al. (2002) & $\begin{array}{l}\text { TCE \& Network } \\
\text { Theory }\end{array}$ & Behavioral & Theoretical Development of MO \\
\hline Martin \& Grbac (2003) & $\begin{array}{l}\text { Resource-based } \\
\text { View }\end{array}$ & Behavioral & $\begin{array}{l}\text { Positive Relationship between MO } \\
\text { and Performance }\end{array}$ \\
\hline $\begin{array}{l}\text { Min, Mentzer \& Ladd } \\
\text { (2007) }\end{array}$ & $\begin{array}{l}\text { Resource-based } \\
\text { View \& } \\
\text { Cooperative } \\
\text { Norms }\end{array}$ & Behavioral & $\begin{array}{l}\text { Positive Relationship between MO } \\
\text { and Performance }\end{array}$ \\
\hline $\begin{array}{l}\text { Inter-firm MO } \\
\text { Theory Network }\end{array}$ & Behavioral & Theoretical Development of IMO \\
\hline Elg (2008) & $\begin{array}{l}\text { Network Theory } \\
\text { Elg \& Paavola (2008) }\end{array}$ & Behavioral & $\begin{array}{l}\text { Theoretical Development of IMO } \\
\text { and Research Propositions }\end{array}$ \\
\hline
\end{tabular}


Table 2: Characteristics of the Sample

\begin{tabular}{|c|c|c|c|c|c|}
\hline \multicolumn{3}{|l|}{ Gender } & \multicolumn{3}{|l|}{ Age Category } \\
\hline & No. & $\%$ & & No. & $\%$ \\
\hline No Answer & 7 & 5 & No Answer & 3 & 2 \\
\hline Female & 18 & 14 & $25-34$ & 19 & 15 \\
\hline Male & 105 & 81 & $35-44$ & 44 & 34 \\
\hline \multirow[t]{3}{*}{ Total } & 130 & 100 & $45-54$ & 50 & 38 \\
\hline & & & $55-64$ & 13 & 10 \\
\hline & & & 65 or older & 1 & 1 \\
\hline \multirow[t]{2}{*}{ No of Employees } & & & Total & 130 & 100 \\
\hline & No. & $\%$ & & & \\
\hline No Answer & 4 & 3 & & & \\
\hline Under 10 & 6 & 5 & Annual Revenues & & \\
\hline 19-Oct & 7 & 5 & & No. & $\%$ \\
\hline $20-49$ & 15 & 12 & No Answer & 5 & 4 \\
\hline $50-149$ & 5 & 4 & Less than $\$ 50,000$ & 2 & 2 \\
\hline $150-499$ & 5 & 4 & $\$ 50,000-\$ 99,999$ & 0 & 0 \\
\hline $500-999$ & 6 & 5 & $\$ 100,000-\$ 499,999$ & 0 & 0 \\
\hline $1000-4999$ & 10 & 8 & $\$ 500,000$ - $\$ 999,999$ & 5 & 4 \\
\hline $5000-9999$ & 2 & 2 & $\$ 1,000,000$ - $\$ 9,999,999$ & 18 & 14 \\
\hline 10000-14999 & 3 & 2 & $\$ 10,000,000$ - $\$ 49,999,999$ & 8 & 6 \\
\hline $15000-24999$ & 3 & 2 & $\$ 50,000,000$ - $\$ 99,999,999$ & 2 & 2 \\
\hline 25000 or more & 56 & 43 & $\$ 100,000,000-\$ 1$ Billion & 7 & 5 \\
\hline Don't Know & 7 & 5 & More than $\$ 1$ Billion & 69 & 53 \\
\hline Prefer not to answer & 1 & 1 & Don't Know & 5 & 4 \\
\hline \multirow[t]{2}{*}{ Total } & 130 & 100 & Prefer not to answer & 9 & 7 \\
\hline & & & Total & 130 & 100 \\
\hline
\end{tabular}


Table 3: Final EFA: Inter-firm Market Orientation Measurement Model

\begin{tabular}{|c|c|c|c|}
\hline & & \multicolumn{2}{|c|}{ Component } \\
\hline & & 1 & 2 \\
\hline \multicolumn{4}{|c|}{ Joint Intelligence Cooperation $(\alpha=0.835)$} \\
\hline Q16c & $\begin{array}{l}\text { We periodically circulate documents (e.g., reports, newsletters) between } \\
\text { companies that provide information on our end users. }\end{array}$ & .901 & \\
\hline Q16e & Data on end users satisfaction are shared with/by this partner on a regular basis. & .689 & \\
\hline Q15e & $\begin{array}{l}\text { We jointly poll end users at least once a year to assess the quality of our } \\
\text { products and services. }\end{array}$ & 670 & \\
\hline Q15c & We do a lot of market research with this partner & .653 & \\
\hline Q15f & $\begin{array}{l}\text { We often jointly talk with or survey those who can influence our end } \\
\text { users purchases. }\end{array}$ & .560 & \\
\hline \multicolumn{4}{|c|}{ Joint Customer Responsiveness $(\alpha=0.782)$} \\
\hline Q17m & $\begin{array}{l}\text { When we find out that end users are unhappy with the quality of our service, we } \\
\text { work with this partner to take corrective action immediately. }\end{array}$ & & .826 \\
\hline Q17n & $\begin{array}{l}\text { When we find that end users would like us to modify a product or service, our } \\
\text { partner involved makes concerted efforts to do so. }\end{array}$ & & .707 \\
\hline Q17i & The joint sales and marketing activities with this partner are well coordinated. & & .565 \\
\hline Q171 & $\begin{array}{l}\text { This partner and I are quick to respond to significant changes in our competitors' } \\
\text { pricing structures. }\end{array}$ & & .542 \\
\hline
\end{tabular}


Table 4: Correlation Matrix for Measurement Model Items

\begin{tabular}{|c|c|c|c|c|c|c|}
\hline & $\mathrm{Q} 15 \mathrm{e}$ & Q16c & Q16e & Q17i & $\mathrm{Q} 17 \mathrm{~m}$ & Q17n \\
\hline $\begin{array}{l}\text { Q15e - We jointly poll end users at least once a year to } \\
\text { assess the quality of our products and services. }\end{array}$ & 1 & & & & & \\
\hline $\begin{array}{l}\text { Q16c - We periodically circulate documents between } \\
\text { companies that provide information on our end users. }\end{array}$ & $.518^{* *}$ & 1 & & & & \\
\hline $\begin{array}{l}\text { Q16e - Data on end-users satisfaction are shared with/by this } \\
\text { partner on a regular basis. }\end{array}$ & $.559^{* *}$ & $.603^{* *}$ & 1 & & & \\
\hline $\begin{array}{l}\text { Q17i - The joint sales and marketing activities with this } \\
\text { partner are well coordinated. }\end{array}$ & $.325^{* *}$ & $.461^{* *}$ & $.411^{* *}$ & 1 & & \\
\hline $\begin{array}{l}\text { Q17m - When we find out that end users are unhappy with } \\
\text { the quality of our service, we work with this partner to take } \\
\text { corrective action immediately. }\end{array}$ & $.301^{* *}$ & $.259^{* *}$ & $.294^{* *}$ & $.488^{* *}$ & 1 & \\
\hline $\begin{array}{l}\text { Q17n - When we find that end users would like us to modify } \\
\text { a product or service, our partner involved makes concerted } \\
\text { efforts to do so. }\end{array}$ & $.309^{* *}$ & $.305^{* *}$ & $.393^{* *}$ & $.542^{* *}$ & $.550^{* *}$ & 1 \\
\hline
\end{tabular}

**. Correlation is significant at the 0.01 level. 
Table 5 - Final EFA components: IMO factors (using 2/3 sample)

\begin{tabular}{|c|c|c|c|}
\hline & & \multicolumn{2}{|c|}{ Component } \\
\hline & & 1 & 2 \\
\hline \multicolumn{4}{|c|}{ Joint Intelligence Cooperation $(\alpha=0.812)$} \\
\hline Q16c & $\begin{array}{l}\text { We periodically circulate documents (e.g., reports, newsletters) between companies } \\
\text { that provide information on our end users. }\end{array}$ & .828 & \\
\hline Q16e & Data on end users satisfaction are shared with/by this partner on a regular basis. & .846 & \\
\hline Q15e & $\begin{array}{l}\text { We jointly poll end users at least once a year to assess the quality of our products and } \\
\text { services. }\end{array}$ & .626 & \\
\hline \multicolumn{4}{|c|}{ Joint Customer Responsiveness $(\alpha=0.767)$} \\
\hline Q17m & $\begin{array}{l}\text { When we find out that end users are unhappy with the quality of our service, we work } \\
\text { with this partner to take corrective action immediately. }\end{array}$ & & .737 \\
\hline Q17n & $\begin{array}{l}\text { When we find that end users would like us to modify a product or service, our partner } \\
\text { involved makes concerted efforts to do so. }\end{array}$ & & 695 \\
\hline Q17i & The joint sales and marketing activities with this partner are well coordinated. & & .646 \\
\hline
\end{tabular}


Table 6 - MIMIC Measurement Model Reliability and Validity Results

\begin{tabular}{|c|c|c|c|c|c|c|}
\hline & & Loading & T Statistics & $\begin{array}{l}\text { Composite } \\
\text { Reliability }\end{array}$ & $\begin{array}{c}\text { Cronbach's } \\
\text { Alpha }\end{array}$ & $\begin{array}{c}\text { Average } \\
\text { Variance } \\
\text { Extracted }\end{array}$ \\
\hline \multirow{3}{*}{$\begin{array}{c}\text { Joint } \\
\text { Intelligence } \\
\text { Cooperation } \\
\text { (JIC) } \\
\end{array}$} & Q15e & 0.813 & 22.679 & \multirow{3}{*}{0.8785} & \multirow{3}{*}{0.7926} & \multirow{3}{*}{0.7069} \\
\hline & Q16c & 0.845 & 26.714 & & & \\
\hline & Q16e & 0.864 & 30.166 & & & \\
\hline \multirow{3}{*}{$\begin{array}{c}\text { Joint Customer } \\
\text { Responsiveness } \\
\text { (JCR) }\end{array}$} & Q17i & 0.831 & 29.022 & \multirow{3}{*}{0.8666} & \multirow{3}{*}{0.7695} & \multirow{3}{*}{0.6842} \\
\hline & $\mathrm{Q} 17 \mathrm{~m}$ & 0.806 & 16.074 & & & \\
\hline & Q17n & 0.844 & 26.859 & & & \\
\hline \multirow{6}{*}{$\begin{array}{l}\text { Inter-firm } \\
\text { Market } \\
\text { Orientation } \\
\text { (IMO) }\end{array}$} & Q15e & 0.672 & 12.656 & \multirow{6}{*}{0.8654} & \multirow{6}{*}{0.8136} & \multirow{6}{*}{0.518} \\
\hline & Q16c & 0.724 & 13.755 & & & \\
\hline & Q16e & 0.744 & 15.979 & & & \\
\hline & Q17i & 0.771 & 19.087 & & & \\
\hline & Q17m & 0.673 & 9.837 & & & \\
\hline & Q17n & 0.729 & 13.708 & & & \\
\hline \multirow{4}{*}{$\begin{array}{l}\text { Relationship } \\
\text { Performance } \\
\text { (RB) }\end{array}$} & $\mathrm{Q} 18 \mathrm{c}$ & 0.805 & 20.902 & \multirow{4}{*}{0.8536} & \multirow{4}{*}{0.596} & \multirow{4}{*}{0.596} \\
\hline & $\mathrm{Q} 18 \mathrm{~d}$ & 0.622 & 7.454 & & & \\
\hline & Q18k & 0.804 & 16.139 & & & \\
\hline & Q181 & 0.838 & 26.822 & & & \\
\hline \multirow{4}{*}{$\begin{array}{l}\text { Business } \\
\text { Performance } \\
\text { (PB) }\end{array}$} & Q9 & 0.641 & 3.233 & \multirow{4}{*}{0.7591} & \multirow{4}{*}{0.6274} & \multirow{4}{*}{0.4528} \\
\hline & Q10 & 0.648 & 2.604 & & & \\
\hline & Q11 & 0.876 & 4.341 & & & \\
\hline & Q12 & 0.461 & 2.065 & & & \\
\hline
\end{tabular}

Fornell-Larker Calculations

\begin{tabular}{c|cccc}
\hline \hline & BP & JCR & JIC & RP \\
\hline BP & $\mathbf{0 . 6 7 3}$ & & & \\
JCR & 0.221 & $\mathbf{0 . 8 2 2}$ & & \\
JIC & 0.187 & 0.493 & $\mathbf{0 . 8 4 1}$ & \\
RP & 0.305 & 0.733 & 0.531 & $\mathbf{0 . 7 7 2}$ \\
\hline \hline
\end{tabular}

Diagonals in bold indicate square root of Average Variance Extracted (AVE) 
Table 7 - Structural Model Results

\begin{tabular}{|c|c|c|c|}
\hline & Path Coefficients & T Statistics & Significance Level \\
\hline $\mathrm{JIC} \rightarrow \mathrm{IMO}$ & 0.550 & 18.026 & 0.01 \\
\hline $\mathrm{JCR} \rightarrow \mathrm{IMO}$ & 0.607 & 17.617 & 0.01 \\
\hline $\mathrm{IMO} \rightarrow \mathrm{RP}$ & 0.738 & 16.649 & 0.01 \\
\hline $\mathrm{IMO} \rightarrow \mathrm{BP}$ & 0.239 & 2.455 & 0.05 \\
\hline
\end{tabular}


Figure 1: Final CFA model of Inter-firm Market Orientation Measurement Model

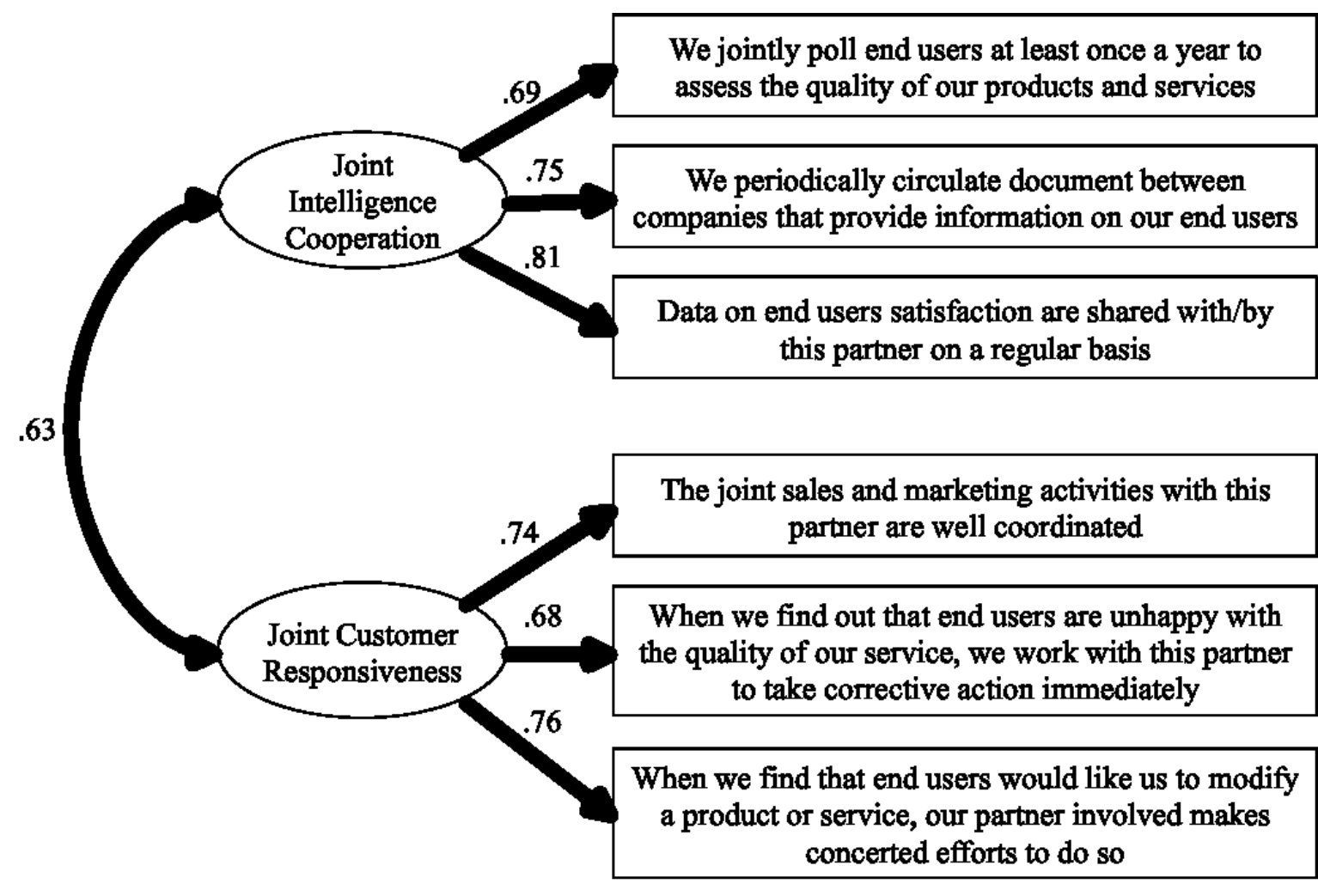

Chi2 $=9.727(\mathrm{df}=8) ; \mathrm{RMR}=0.039 ; \mathrm{SRMR}=0.0345 ; \mathrm{GFI}=0.975 . \mathrm{CFI}=0.993 ; \mathrm{RMSEA}=0.041$

All parameters are significant to the 0.01 level 
Figure 2 - MIMIC Model to Test Second-Order IMO Construct



JIC - Joint Intelligence Cooperation

JCR - Joint Customer Responsiveness

IMO - Inter-firm Market Orientation

RP - Relationship Performance

BP - Business Performance 


\section{Appendix - The original 31 IMO items}

Scale Items

\begin{tabular}{|c|c|c|}
\hline $\begin{array}{c}\text { Item } \\
\#\end{array}$ & $\begin{array}{l}\text { Variable } \\
\text { Name }\end{array}$ & INTER-FIRM MO - JOINT INTELLIGENCE GENERATION \\
\hline 1 & Q15a & $\begin{array}{l}\text { Jointly with this partner, we meet with end users at least once a year to find out what products } \\
\text { or services they will need in the future. }\end{array}$ \\
\hline 2 & Q15b & $\begin{array}{l}\text { Jointly, individuals from our internally facing departments (e.g. manufacturing or tech } \\
\text { support) interact directly with end users to learn how to serve them better. }\end{array}$ \\
\hline 3 & Q15c & We do a lot of market research with this partner. \\
\hline 4 & Q15d & $\begin{array}{l}\text { In this partner relationship, we are slow to detect changes in our end users' product } \\
\text { preferences. (R) }\end{array}$ \\
\hline 5 & Q15e & $\begin{array}{l}\text { We jointly poll end users at least once a year to assess the quality of our products and } \\
\text { services. }\end{array}$ \\
\hline 6 & Q15f & We often jointly talk with or survey those who can influence our end users purchases. \\
\hline 7 & Q15g & We jointly collect industry information through informal means. \\
\hline 8 & Q15h & Market intelligence on our competitors is generated independently by each partner. \\
\hline 9 & Q15i & $\begin{array}{l}\text { Thinking about this partner relationship, we are slow to jointly detect fundamental shifts in } \\
\text { our industry (e.g., competition, technology, regulation). (R) }\end{array}$ \\
\hline 10 & Q15j & $\begin{array}{l}\text { Jointly we periodically review the likely effect of changes in our business environment (e.g., } \\
\text { regulation) on end users. }\end{array}$ \\
\hline $\begin{array}{c}\text { Item } \\
\#\end{array}$ & $\begin{array}{l}\text { Variable } \\
\text { Name }\end{array}$ & INTER-FIRM MO - JOINT INTELLIGENCE DISSEMINATION CONSTRUCT \\
\hline 11 & Q16a & $\begin{array}{l}\text { With this partner, we have meetings at least once a quarter to discuss market trends and } \\
\text { developments. }\end{array}$ \\
\hline 12 & Q16b & We spend time, with this partner, discussing end users' future needs. \\
\hline 13 & Q16c & $\begin{array}{l}\text { We periodically circulate documents (e.g., reports, newsletters) between companies that } \\
\text { provide information on our end users. }\end{array}$ \\
\hline 14 & Q16d & $\begin{array}{l}\text { When something important happens to a major end users or market, both partners know about } \\
\text { it in a short period. }\end{array}$ \\
\hline 15 & Q16e & Data on end users satisfaction are shared with/by this partner on a regular basis. \\
\hline 16 & Q16f & There is minimal communication with this partner concerning market developments. (R) \\
\hline 17 & Q16g & $\begin{array}{l}\text { When one partner finds out something important about competitors, it is slow to alert other } \\
\text { the other partner. }(\mathrm{R})\end{array}$ \\
\hline
\end{tabular}

\begin{tabular}{ccc}
\hline Item & $\begin{array}{c}\text { Variable } \\
\text { Name }\end{array}$ & INTER-FIRM MO - JOINT RESPONSIVENESS CONSTRUCT \\
\hline
\end{tabular}

18 Q17a Thinking about this partner, it takes us forever to jointly decide how to respond to our competitors' price changes. (R)

19 Q17b Principles of market segmentation drive joint new solution development efforts in this business.

$20 \quad$ Q17c

Thinking about this partner, for one reason or another we tend to ignore changes in our end users' product or service needs. (R) 
21 Q17d We periodically jointly review our product offerings to ensure that they are in line with what end users want.

$22 \quad$ Q17e

Our joint business plans are driven more by technological advances than by market research. (R)

$23 \quad$ Q17f

We work with this partner periodically to plan a joint response to changes taking place in our business environment.

24 Q17g The product solution we choose to jointly sell with this partner depend more on the politics with this partner than real market needs. (R)

25 Q17h If a major competitor were to launch an intensive campaign targeted at our end users, we would implement a joint response immediately with this partner.

26 Q17i The joint sales and marketing activities with this partner are well coordinated.

$27 \quad$ Q17j End users complaints fall on deaf ears in this partnership. (R)

28 Q17k Even if we came up with a great partner-marketing plan, we probably would not be able to jointly implement it in a timely fashion. (R)

$29 \quad$ Q171 This partner and I are quick to respond to significant changes in our competitors' pricing structures.

30 Q17m When we find out that end users are unhappy with the quality of our service, we work with this partner to take corrective action immediately.

31 Q17n When we find that end users would like us to modify a product or service, our partner involved makes concerted efforts to do so.

Bolded items indicate final items in measurement model 